\title{
Effects of forage source and extruded linseed supplementation on methane emissions from growing dairy cattle of differing body weights
}

\author{
K. J. Hammond, D. J. Humphries, L. A. Crompton, P. Kirton, and C. K. Reynolds ${ }^{1}$ \\ Food Production and Quality Division, Centre for Dairy Research, School of Agriculture, Policy and Development, University of Reading, \\ PO Box 237, Earley Gate, Reading, RG6 6AR, United Kingdom
}

\begin{abstract}
Changes in diet carbohydrate amount and type (i.e., starch vs. fiber) and dietary oil supplements can affect ruminant methane emissions. Our objectives were to measure methane emissions, whole-tract digestibility, and energy and nitrogen utilization from growing dairy cattle at 2 body weight (BW) ranges, fed diets containing either high maize silage (MS) or high grass silage (GS), without or with supplemental oil from extruded linseed (ELS). Four Holstein-Friesian heifers aged 13 mo (BW range from start to finish of 382 to $526 \mathrm{~kg}$ ) were used in experiment 1, whereas 4 lighter heifers aged 12 mo (BW range from start to finish of 292 to $419 \mathrm{~kg}$ ) were used in experiment 2. Diets were fed as total mixed rations with forage dry matter (DM) containing high MS or high GS and concentrates in proportions (forage:concentrate, DM basis) of either 75:25 (experiment 1) or 60:40 (experiment 2), respectively. Diets were supplemented without or with ELS (Lintec, BOCM Pauls Ltd., Wherstead, UK; $260 \mathrm{~g}$ of oil $/ \mathrm{kg}$ of $\mathrm{DM}$ ) at $6 \%$ of ration DM. Each experiment was a $4 \times 4$ Latin square design with 33 -d periods, with measurements during d 29 to 33 while animals were housed in respiration chambers. Heifers fed MS at a heavier BW (experiment 1) emitted 20\% less methane per unit of DM intake (yield) compared with GS (21.4 vs. 26.6, respectively). However, when repeated with heifers of a lower BW (experiment 2), methane yield did not differ between the 2 diets $(26.6 \mathrm{~g} / \mathrm{kg}$ of DM intake). Differences in heifer BW had no overall effect on methane emissions, except when expressed as grams per kilogram of digestible organic matter (OMD) intake (32.4 vs. 36.6, heavy vs. light heifers). Heavier heifers fed MS in experiment 1 had a greater DM intake (9.4 $\mathrm{kg} / \mathrm{d})$ and lower OMD $(755 \mathrm{~g} / \mathrm{kg})$, but no difference in $\mathrm{N}$ utilization ( $31 \%$ of $\mathrm{N}$ intake) compared with heifers fed GS $(7.9 \mathrm{~kg} / \mathrm{d}$ and $799 \mathrm{~g} / \mathrm{kg}$, respectively). Tissue energy retention was nearly double for heifers fed MS
\end{abstract}

Received April 4, 2015.

Accepted July 15, 2015.

${ }^{1}$ Corresponding author: c.k.reynolds@reading.ac.uk compared with GS in experiment 1 (15 vs. $8 \%$ of energy intake, respectively). Heifers fed MS in experiment 2 had similar DM intake $(7.2 \mathrm{~kg} / \mathrm{d})$ and retention of energy ( $5 \%$ of intake energy) and $\mathrm{N}$ ( $28 \%$ of $\mathrm{N}$ intake), compared with GS-fed heifers, but OMD was lower (741 vs. $765 \mathrm{~g} / \mathrm{kg}$, respectively). No effect of ELS was noted on any of the variables measured, irrespective of animal BW, and this was likely due to the relatively low amount of supplemental oil provided. Differences in heifer BW did not markedly influence dietary effects on methane emissions. Differences in methane yield were attributable to differences in dietary starch and fiber composition associated with forage type and source.

Key words: methane, dairy cattle, forage, oil supplementation

\section{INTRODUCTION}

The farming of ruminant livestock is a major source of greenhouse gas emissions, including methane, which has 25 times greater global warming potential than carbon dioxide (g/g basis; United Nations, 2009). Enteric methane not only contributes to greenhouse gas emissions, but also represents a substantial waste of feed energy for ruminant animals. Greater knowledge of factors that determine emissions could lead to reduced environmental effects and improvements in dietary energy utilization for ruminant-derived food production. Several methane-mitigation opportunities have been identified, including changes in diet carbohydrate amount and type as well as the use of dietary oil supplements to decrease methane emissions (Cottle et al., 2011; Grainger and Beauchemin 2011).

Maize silage- (MS) and grass silage (GS)-based diets are representative of typical rations fed to cattle in the United Kingdom. In particular, MS has been used increasingly in livestock diets as newer varieties with shorter growing seasons become available (O'Mara et al., 1998). Maize silage typically has high DM yields, providing biomass that is readily digestible and increases voluntary feed intake and animal performance (O'Mara et al., 1998; Beauchemin et al., 2008). Forage composition can vary considerably and depends on for- 
age species and maturity at harvest. Maize silage has a digestible starch content of approximately $30 \%$, whereas the major carbohydrate of GS is NDF (Brask et al., 2013). The contrasting carbohydrate profile of MS versus GS gives the expectation of differing methane emissions when they are fed to ruminants (Beauchemin et al., 2008). A greater starch intake can result in a lower rumen $\mathrm{pH}$ and enhanced propionate production, which is an alternative hydrogen sink to methane (Janssen, 2010) and is less favorable for fibrolytic bacteria (Owens et al., 2009). In contrast, increasing grass maturity increases NDF concentration and acetate is a major end product of NDF fermentation, with acetate production enhancing methane formation (Johnson and Johnson, 1995). Studies have reported decreased methane emission from ruminants when replacing GS with MS (Reynolds et al., 2010; Brask et al., 2013; van Gastelen et al., 2015), although some have reported no effect (Staerfl et al., 2012; Livingstone et al., 2015), and thus more research is needed.

In addition to alterations in dietary fiber and starch, the feeding of supplemental oil will typically reduce methane emissions by an amount dependent on the quantity fed (Beauchemin et al., 2008). However, the amount of oil supplemented in the diet can have detrimental effects on feed intake, digestibility, and fermentation of feeds, including animal performance, depending in part on the type and form of the oil fed (Patra, 2013). Oils in the diet replace fermentable substrates and PUFA provide an alternative to methane synthesis for hydrogen disposal as well as having direct inhibitory effects on the rumen microflora (Martin et al., 2010). It was found that for a $1 \%$ increase of oil supplementation, methane yield $(\mathrm{g} / \mathrm{kg}$ of DMI) was reduced to a similar extent across various studies (0.79, Moate et al. 2011; 1.00, Grainger and Beauchemin, 2011; and 0.66, Patra, 2013). Renewed interest into the effects of linolenic acid (C18:3 n-3), including extruded linseed (Martin et al., 2008; Livingstone et al., 2015), on methane emissions has been noted. Linolenic acid has been found to decrease the number and activity of ruminal protozoa, cellulolytic bacteria (Nagaraja et al., 1997), and methanogens, either directly or indirectly affecting methanogenesis (Morgavi et al., 2010). However, the extent to which linolenic acid provided by linseed products and fed at practical levels of feeding decrease methane emissions are not certain (Livingstone et al., 2015).

The objectives of the present study were to determine the effects of feeding high-MS and high-GS diets, without or with supplemental oil from extruded linseed, on methane emissions, whole-tract digestibility, and energy and $\mathrm{N}$ balance in growing dairy cattle. Measurements were obtained using 2 groups of growing heifers with differing BW ranges. It was hypothesized that heifers fed a high-MS diet would have increased retention of energy and $\mathrm{N}$, which would be associated with lower methane yields ( $\mathrm{g} / \mathrm{kg}$ of DMI), compared with heifers fed high-GS diets, and that ELS supplementation would reduce methane yield for both MS- and GS-based diets.

\section{MATERIALS AND METHODS}

\section{Experimental Design}

Both experiments were conducted at the University of Reading Centre for Dairy Research, between January and May 2011 for experiment 1 and December 2011 and April 2012 for experiment 2. Dietary treatments for both experiments were provided in a $4 \times 4$ Latin square design balanced for carry over effects with 33 -d periods. From d 1 to 28 animals were group-housed and bedded on wood shavings with rubber mats and adapted to dietary treatments, with feed intakes measured using an electronic Calan Broadbent individual feeding system (American Calan, Northwood, NH). From d 29 to 33 animals were housed in individual respiration chambers where measurements of diet composition, intake, fecal and urine excretion, and energy and $\mathrm{N}$ excretion were undertaken, with oxygen consumption and methane and carbon dioxide excretion measured over the last 4 d. All animal procedures were conducted in accordance with the UK Animals (Scientific Procedures) Act, 1996.

\section{Animals and Dietary Treatments}

Four Holstein Friesian dairy heifers aged 13 mo with a BW range that spanned the experimental duration (from start to finish, respectively) of 382 to $526 \mathrm{~kg}$, were used in experiment 1 , and 4 lighter Holstein Friesian heifers, aged $12 \mathrm{mo}$, with a BW range from start to finish of the experimental duration of 292 to $419 \mathrm{~kg}$ were used for experiment 2. Body weight was measured weekly and when heifers entered and left the respiration chambers. Dietary treatments were fed once daily at $1000 \mathrm{~h}$ for intakes to achieve live weight gains (LWG) of $1 \mathrm{~kg} / \mathrm{d}$ for experiment 1 and $0.75 \mathrm{~kg} / \mathrm{d}$ for experiment 2 using estimates of diet ME concentrations and ME requirements for target LWG (Alderman and Cottrill, 1993). Target LWG for experiment 2 was lower to minimize feed refusals. In experiment 2 , the diets were adjusted to incorporate approximately $1 \mathrm{~kg}$ of $\mathrm{DM} / \mathrm{d}$ of commercial calf pellet [chemical composition $(\mathrm{g} / \mathrm{kg}$ of $\mathrm{DM})$ of ash $=85.1 ;$ oil $=46.5 ; \mathrm{ADF}=174$; $\mathrm{NDF}=289$; starch $=259$; water-soluble carbohydrate $(\mathbf{W S C H O})=91.3 ; \mathrm{CP}=171 ;$ and gross energy $(\mathbf{G E}$, 
Table 1. Diet formulation (g/kg of DM) with 2 ratios of maize (MS) to grass silage (GS), supplemented without or with extruded linseed [ELS; MS with ELS (ML) and GS with ELS (GL)] for experiments 1 and 2

\begin{tabular}{|c|c|c|c|c|c|c|c|c|}
\hline \multirow[b]{2}{*}{ Item } & \multicolumn{4}{|c|}{ Experiment 1} & \multicolumn{4}{|c|}{ Experiment 2} \\
\hline & MS & ML & GS & GL & MS & ML & GS & GL \\
\hline Cracked wheat & 50 & 0 & 186 & 136 & 40 & 0 & 195 & 160 \\
\hline Soybean meal & 175 & 165 & 39 & 29 & 160 & 150 & 10 & 0 \\
\hline Minerals & 25 & 25 & 25 & 25 & 20 & 20 & 20 & 20 \\
\hline
\end{tabular}

${ }^{1}$ Lintec, BOCM Pauls Ltd., Wherstead, UK.

$\mathrm{MJ}$ of $\mathrm{ME} / \mathrm{kg}$ of $\mathrm{DM})=18.1$ for each heifer as part of another experiment comparing methane measurement techniques (Hammond et al., 2015).

Four experimental diets were fed as TMR with forage DM composed of MS (1) or GS (2), with forage-toconcentrate proportions (DM basis) of 75:25 (experiment 1) and 60:40 (experiment 2), without or with supplemental oil from extruded linseed (ELS; $260 \mathrm{~g}$ of oil $/ \mathrm{kg}$ of DM) at $6 \%$ of ration DM [i.e., maize silage with ELS (3; ML) and grass silage with ELS (4; GL)]. The amount of ELS fed was slightly higher than fed in a previous study (5\% DM basis) at our location (Livingstone et al., 2015), which was roughly twice dietary inclusion rates recommended by the supplier for lactating dairy cow diets. Diets were formulated to be isonitrogenous using varying amounts of cracked wheat and soybean meal (Table 1). Minerals were also included in the rations. The amount of forage included in the diets was reduced for experiment 2 to enable isonitrogenous formulation based on preliminary forage analyses and inclusion of calf pellets in the TMR.

Both MS and GS were prepared from material harvested in 2010 for experiment 1 and in 2011 for experiment 2. The MS used for both experiments was based on a mixture of maize varieties which were combined at harvest and ensiled in clamps. The GS for both experiments was made from a Lolium perenne mixture containing medium and later maturing varieties of tetra and diploid ryegrass species. The GS was wilted for $24 \mathrm{~h}$ and ensiled with an additive (Genus ULV, Genus Breeding Ltd., Nantwich, UK, $40 \mathrm{~mL} / \mathrm{t}$ ). Both MS and GS silage clamps remained sealed for a minimum period of 6 wk before use.

\section{Energy and Nitrogen Utilization}

Measurements of energy and $\mathrm{N}$ balance were as described by Cammell et al. (1986) and Reynolds et al. (2014). Open-circuit respiration chambers were used and calibrated as described by Hammond et al. (2014) for measurements of oxygen consumption and carbon dioxide and methane excretion over a 4-d period. Heat production was calculated using the Brouwer equation (Brouwer, 1965).

\section{Sample Collection and Analyses}

The TMR offered and refused, and feces and urine were collected daily from individual heifers for the period they were housed in respiration chambers (Hammond et al., 2014). Daily DM measurements were made for TMR offered, but for refusal and fecal DM measurements were made on an individual heifer's composite sample taken while in respiration chambers. An additional composite sample of the TMR offered and refused as well as feces for individual heifers was also taken and stored frozen at $-20^{\circ} \mathrm{C}$ for subsequent analyses. Individual daily urine output was collected in containers with $10 \mathrm{~N}$ sulfuric acid to maintain urine $\mathrm{pH}$ below 2 after $24 \mathrm{~h}$ (Reynolds et al., 2014). At the end of each period, the urine was thawed, mixed, and a volume-adjusted composite was taken and stored frozen for subsequent analysis.

Details of sample analyses are given in Hammond et al. (2014). Briefly, the pooled composite samples stored at $-20^{\circ} \mathrm{C}$ (TMR offered and refused as well as feces and urine) were prepared for analyses of $\mathrm{N}$ (macro Kjeldahl method), GE (combustion using an adiabatic bomb calorimeter), and wet chemistry (TMR offered and refused as well as feces) to determine NDF and ADF (procedure of Robertson and Van Soest, 1981), oil (acid extraction), ash (combustion), and WSCHO (Nelson-Somogyi procedure). Analyses were used to determine individual dietary component intakes for each heifer (offered less refusal), as well as for calculation of energy and $\mathrm{N}$ utilization (component intake, feces and urine), as described by Cammell et al. (2000).

\section{Statistical Analyses}

Means of variables measured for each heifer from $\mathrm{d}$ 29 to 33 of each period were used in the statistical 
Table 2. Chemical composition (DM basis, $\mathrm{g} / \mathrm{kg}$, unless otherwise stated) of high-maize (MS) or high-grass silage (GS) diets supplemented without or with extruded linseed [ELS; MS with ELS (ML) and GS with ELS (GL)] for experiments 1 and 2

\begin{tabular}{|c|c|c|c|c|c|c|c|c|}
\hline \multirow[b]{2}{*}{ Item } & \multicolumn{4}{|c|}{ Diet and treatment } & \multirow[b]{2}{*}{ SEM } & \multicolumn{3}{|c|}{$P$-value } \\
\hline & MS & ML & GS & GL & & Diet (D) & ELS & $\mathrm{D} \times \mathrm{ELS}$ \\
\hline $\mathrm{DM}, \mathrm{g} / \mathrm{kg}$ of fresh matter & 506 & 505 & 396 & 403 & 5.91 & 0.001 & 0.644 & 0.582 \\
\hline $\mathrm{OM}$ & 949 & 947 & 951 & 948 & 1.10 & 0.033 & 0.017 & 0.247 \\
\hline $\mathrm{CP}$ & 144 & 146 & 181 & 176 & 3.89 & 0.001 & 0.676 & 0.366 \\
\hline NDF & 267 & 288 & 379 & 385 & 8.04 & 0.001 & 0.142 & 0.400 \\
\hline Water-soluble carbohydrate & 25.2 & 26.2 & 24.1 & 29.6 & 3.44 & 0.675 & 0.512 & 0.965 \\
\hline Oil & 36.1 & 49.3 & 41.5 & 54.6 & 1.12 & 0.005 & 0.001 & 0.991 \\
\hline \multicolumn{9}{|l|}{ Experiment 2} \\
\hline $\mathrm{DM}, \mathrm{g} / \mathrm{kg}$ of fresh matter & 479 & 485 & 516 & 519 & 6.03 & 0.001 & 0.479 & 0.779 \\
\hline $\mathrm{OM}$ & 960 & 958 & 968 & 967 & 0.77 & 0.001 & 0.001 & 0.912 \\
\hline $\mathrm{CP}$ & 146 & 146 & 148 & 146 & 4.96 & 0.926 & 0.793 & 0.866 \\
\hline $\mathrm{NDF}$ & 315 & 336 & 332 & 343 & 5.14 & 0.019 & 0.005 & 0.231 \\
\hline
\end{tabular}

analysis. Data for each experiment were analyzed using the mixed procedure of SAS (version 9.3, SAS Institute Inc., Cary, NC) for the fixed effect of forage type (1 df), ELS (1 df), and their interaction (1 df), and random effects of heifer $(3 \mathrm{df})$ and period $(3 \mathrm{df})$, with period as a repeated effect. Each variable was tested using different covariance structures (compound symmetry, heterogeneous compound symmetry, autoregressive, heterogeneous autoregressive, or unstructured), with the structure giving the best fit, based on lowest BIC value, used in the model. Data from each experiment were combined and analyzed using the mixed procedure of SAS for the effect of BW class on diet composition, feed intake, whole-tract apparent digestibility, and methane emissions. Least squares means are reported and dietary treatment effects were considered significant at $P<0.10$.

\section{RESULTS}

\section{Diet Formulation and Chemical Composition Offered}

For experiment 1, starch concentration was almost 3 fold greater $(P<0.01)$ for MS compared with GS diets, but MS diets had lower $(P<0.05)$ concentrations of CP, NDF, ADF, and oil (Table 2). No difference between diets in WSCHO concentration was observed. Diets with ELS in experiment 1 had less OM $(P<$ $0.02)$ and starch $(P<0.01)$ and greater $\operatorname{ADF}(P<$ $0.06)$ and oil $(P<0.01)$ concentrations. For experiment 2, MS diets had a 1.5 fold greater $(P<0.01)$ starch concentration, lower $(P<0.01) \mathrm{OM}$ content, and lower $(P<0.03)$ concentrations of NDF, ADF, WSCHO, and oil compared with GS diets. No difference in CP concentration was noted between diets. Extruded linseed supplementation in experiment 2 increased $(P<$ $0.01)$ concentrations of NDF and oil and decreased $(P$ $<0.01)$ starch concentration.

\section{BW, Feed Intake, and Apparent Total-Tract Digestibility}

Heifers used in experiment 1 averaged $451 \mathrm{~kg}$ (Table 3 ), whereas heifers in experiment 2 averaged $362 \mathrm{~kg}$ (Table 4). Heifers fed MS in experiment 1 weighed more $(P<0.01)$ than those fed GS; however, diet had no effect on heifer BW in experiment 2. Extruded linseed supplementation had no effect on heifer BW for either experiment. Over the course of experiments 1 and 2, heifers gained $( \pm$ SEM $) 1.08 \pm 0.04$ and $0.85 \pm 0.03$ $\mathrm{kg} / \mathrm{d}$, respectively.

For experiment 1, heifers fed MS consumed more DM $(P<0.01)$ than when fed GS, and had greater intakes of $\mathrm{OM}(P<0.01)$ and starch $(P<0.02)$, but lower intakes $(P<0.05)$ of $\mathrm{NDF}$ and ADF (Table 3$)$. No effects of diet were observed on intakes of CP, WSCHO, or oil. Extruded linseed supplementation did not affect individual component intakes except for an increased $(P=0.04)$ intake of oil. Total-tract DM digestibility (DMD) was not affected by diet (Table 3); however, total-tract digestibility $(\mathrm{g} / \mathrm{kg})$ of $\mathrm{OM}(\mathrm{OMD}), \mathrm{CP}$, $\mathrm{NDF}$, and ADF were lower $(P<0.10)$ and starch was greater $(P<0.08)$ for heifers fed MS compared with GS diets. There was no effect of ELS on digestibility of nutrients in the present study. 
Table 3. Body weight $(\mathrm{kg})$, component intake $(\mathrm{kg} / \mathrm{d})$, gross energy $(\mathrm{GE})$ intake $(\mathrm{MJ} / \mathrm{d})$, and total-tract digestibility (g/kg) of nutrients in growing dairy heifers fed high-maize (MS) or high-grass silage (GS) diets supplemented without or with extruded linseed [ELS; MS with ELS (ML) and GS with ELS (GL)] in experiment 1

\begin{tabular}{|c|c|c|c|c|c|c|c|c|}
\hline \multirow[b]{2}{*}{ Item } & \multicolumn{4}{|c|}{ Diet and treatment } & \multirow[b]{2}{*}{ SEM } & \multicolumn{3}{|c|}{$P$-value } \\
\hline & MS & ML & GS & GL & & Diet (D) & ELS & $\mathrm{D} \times \mathrm{ELS}$ \\
\hline $\mathrm{BW}$ & 454 & 454 & 448 & 447 & 13.1 & 0.007 & 0.571 & 0.684 \\
\hline \multicolumn{9}{|l|}{ Component intake } \\
\hline $\mathrm{DM}$ & 9.29 & 9.46 & 7.94 & 7.89 & 0.39 & 0.003 & 0.603 & 0.415 \\
\hline $\mathrm{OM}$ & 8.81 & 8.96 & 7.56 & 7.50 & 0.37 & 0.003 & 0.661 & 0.391 \\
\hline $\mathrm{CP}$ & 1.42 & 1.39 & 1.39 & 1.37 & 0.08 & 0.461 & 0.492 & 0.936 \\
\hline NDF & 2.59 & 2.71 & 2.84 & 2.94 & 0.16 & 0.019 & 0.168 & 0.869 \\
\hline $\mathrm{ADF}$ & 1.64 & 1.69 & 1.73 & 1.91 & 0.10 & 0.010 & 0.189 & 0.359 \\
\hline Starch & 3.32 & 2.74 & 0.85 & 0.83 & 0.12 & 0.023 & 0.145 & 0.176 \\
\hline Water-soluble carbohydrate & 0.26 & 0.25 & 0.29 & 0.20 & 0.04 & 0.193 & 0.851 & 0.943 \\
\hline Oil & 0.34 & 0.46 & 0.34 & 0.43 & 0.02 & 0.256 & 0.040 & 0.201 \\
\hline \multicolumn{9}{|l|}{ Apparent digestibility } \\
\hline DM & 729 & 744 & 760 & 750 & 10.0 & 0.176 & 0.898 & 0.323 \\
\hline $\mathrm{OM}$ & 749 & 760 & 800 & 798 & 5.40 & 0.003 & 0.429 & 0.270 \\
\hline $\mathrm{CP}$ & 661 & 652 & 674 & 712 & 20.6 & 0.087 & 0.462 & 0.231 \\
\hline NDF & 556 & 535 & 770 & 776 & 19.4 & 0.001 & 0.679 & 0.524 \\
\hline $\mathrm{ADF}$ & 550 & 516 & 703 & 732 & 22.5 & 0.013 & 0.567 & 0.077 \\
\hline Starch & 987 & 991 & 982 & 979 & 3.79 & 0.084 & 0.917 & 0.413 \\
\hline
\end{tabular}

For experiment 2, DMI was similar $(P=0.15)$ for heifers fed MS and GS diets. Heifers fed MS diets consumed more starch $(P<0.01)$ but less $(P<0.01)$ OM, $\mathrm{CP}, \mathrm{NDF}$, and WSCHO compared with GS diets (Table 4). Extruded linseed supplementation increased intakes of CP $(P<0.09)$, NDF $(P<0.02)$, ADF $(P<0.05)$ and oil $(P<0.01)$, but decreased $(P<0.04)$ intake of starch. An interaction $(P<0.01)$ was noted between diet and ELS for dietary oil intake, with a much greater increase in oil intake with ELS for GS compared with MS diets. Total-tract digestibility of DM and starch were not affected $(P>0.12)$ by forage type (Table 4$)$, but for MS diets heifers had a lower OMD $(P<0.04)$ and greater $(P<0.05)$ digestibility of $\mathrm{CP}, \mathrm{NDF}$, and ADF compared with GS diets. The ELS increased CP digestibility $(P<0.08)$ and decreased NDF digestibility $(P<0.09)$.

\section{Methane Emissions and Respiratory Exchange}

For heifers of experiment 1, daily methane production $\left(\mathrm{g} / \mathrm{d}\right.$ and $\left.\mathrm{g} / \mathrm{kg} \mathrm{BW}^{0.75}\right)$ was similar between MS

Table 4. Body weight $(\mathrm{kg})$, component intake $(\mathrm{kg} / \mathrm{d})$, gross energy $(\mathrm{GE})$ intake $(\mathrm{MJ} / \mathrm{d})$, and total-tract digestibility $(\mathrm{g} / \mathrm{kg})$ of nutrients in growing dairy heifers fed high-maize (MS) or high-grass silage (GS) diets supplemented without or with extruded linseed [ELS; MS with ELS (ML) and GS with ELS (GL)] in experiment 2

\begin{tabular}{|c|c|c|c|c|c|c|c|c|}
\hline \multirow[b]{2}{*}{ Item } & \multicolumn{4}{|c|}{ Diet and treatment } & \multirow[b]{2}{*}{ SEM } & \multicolumn{3}{|c|}{$P$-value } \\
\hline & MS & ML & GS & GL & & Diet (D) & ELS & $\mathrm{D} \times \mathrm{ELS}$ \\
\hline BW & 361 & 364 & 361 & 365 & 7.58 & 0.349 & 0.292 & 0.451 \\
\hline \multicolumn{9}{|l|}{ Component intake } \\
\hline DM & 7.03 & 7.16 & 7.28 & 7.42 & 0.24 & 0.146 & 0.418 & 0.962 \\
\hline $\mathrm{OM}$ & 6.74 & 6.84 & 7.05 & 7.37 & 0.21 & 0.027 & 0.185 & 0.466 \\
\hline $\mathrm{CP}$ & 1.01 & 1.04 & 1.07 & 1.13 & 0.03 & 0.058 & 0.093 & 0.233 \\
\hline $\mathrm{NDF}$ & 2.20 & 2.37 & 2.38 & 2.60 & 0.08 & 0.020 & 0.020 & 0.580 \\
\hline $\mathrm{ADF}$ & 1.63 & 1.88 & 1.68 & 1.95 & 0.05 & 0.096 & 0.051 & 0.189 \\
\hline Starch & 1.85 & 1.70 & 1.33 & 1.21 & 0.07 & 0.001 & 0.036 & 0.779 \\
\hline Water-soluble carbohydrate & 0.20 & 0.19 & 0.78 & 0.77 & 0.04 & 0.017 & 0.775 & 0.861 \\
\hline Oil & 0.65 & 0.67 & 0.53 & 0.84 & 0.06 & 0.286 & 0.006 & 0.009 \\
\hline \multicolumn{9}{|l|}{ Apparent digestibility } \\
\hline $\mathrm{DM}$ & 714 & 727 & 728 & 742 & 10.1 & 0.117 & 0.135 & 0.969 \\
\hline $\mathrm{OM}$ & 736 & 746 & 756 & 773 & 9.94 & 0.036 & 0.157 & 0.667 \\
\hline $\mathrm{CP}$ & 666 & 683 & 609 & 641 & 14.2 & 0.013 & 0.075 & 0.419 \\
\hline $\mathrm{NDF}$ & 573 & 533 & 473 & 451 & 0.85 & 0.025 & 0.090 & 0.238 \\
\hline $\mathrm{ADF}$ & 510 & 554 & 576 & 650 & 38.1 & 0.086 & 0.186 & 0.710 \\
\hline Starch & 986 & 984 & 987 & 981 & 3.99 & 0.843 & 0.403 & 0.728 \\
\hline
\end{tabular}


Table 5. Methane emissions of growing dairy heifers fed high-maize (MS) or high-grass silage (GS) diets supplemented without or with extruded linseed [ELS; MS with ELS (ML) and GS with ELS (GL)] for experiments 1 and 2

\begin{tabular}{|c|c|c|c|c|c|c|c|c|}
\hline \multirow[b]{2}{*}{ Methane emissions ${ }^{1}$} & \multicolumn{4}{|c|}{ Diet and treatment } & \multirow[b]{2}{*}{ SEM } & \multicolumn{3}{|c|}{$P$-value } \\
\hline & MS & ML & GS & GL & & $\operatorname{Diet}(\mathrm{D})$ & ELS & $\mathrm{D} \times \mathrm{ELS}$ \\
\hline \multicolumn{9}{|l|}{$\overline{\text { Experiment } 1}$} \\
\hline $\mathrm{g} / \mathrm{d}$ & 220 & 197 & 203 & 201 & 14.4 & 0.588 & 0.311 & 0.400 \\
\hline $\mathrm{g} / \mathrm{kg}$ of DMI & 22.3 & 20.4 & 27.0 & 26.2 & 1.24 & 0.001 & 0.174 & 0.569 \\
\hline $\mathrm{g} / \mathrm{kg}$ of $\mathrm{OMI}$ & 23.6 & 21.6 & 28.3 & 27.6 & 1.30 & 0.001 & 0.202 & 0.496 \\
\hline $\mathrm{g} / \mathrm{kg}$ of OMD intake & 32.6 & 28.9 & 34.0 & 34.3 & 1.47 & 0.073 & 0.146 & 0.126 \\
\hline $\mathrm{g} / \mathrm{d}$ & 184 & 193 & 208 & 192 & 11.4 & 0.350 & 0.746 & 0.317 \\
\hline $\mathrm{g} / \mathrm{kg}$ of DMI & 26.1 & 27.0 & 28.5 & 26.0 & 1.99 & 0.728 & 0.681 & 0.397 \\
\hline $\mathrm{g} / \mathrm{kg}$ of $\mathrm{OMI}$ & 27.3 & 28.2 & 29.4 & 23.7 & 1.84 & 0.598 & 0.323 & 0.178 \\
\hline $\mathrm{g} / \mathrm{kg}$ of OMD intake & 36.9 & 37.9 & 38.9 & 30.2 & 2.51 & 0.366 & 0.238 & 0.155 \\
\hline $\mathrm{g} / \mathrm{kg}$ of $\mathrm{BW}^{0.75}$ & 2.28 & 2.33 & 2.46 & 2.29 & 0.15 & 0.625 & 0.673 & 0.432 \\
\hline
\end{tabular}

${ }^{1} \mathrm{OMI}=\mathrm{OM}$ intake; $\mathrm{OMD}=\mathrm{OM}$ digestibility.

and GS diets, averaging $205 \mathrm{~g} / \mathrm{d}$ and $2.1 \mathrm{~g} / \mathrm{kg}$ of $\mathrm{BW}^{0.75}$ (Table 5). When methane was expressed relative to DMI (methane yield), heifers fed MS emitted nearly $20 \%$ less $(P<0.01)$ than when fed GS $(21.4$ vs. $26.6 \mathrm{~g} / \mathrm{kg}$ of DMI, respectively), and differences in methane emission remained significant when expressed as grams per kilogram of OMI $(P<0.01)$ and grams per kilogram of OMD intake $(P<0.07)$. No effect of ELS on methane emissions was observed in heifers of experiment 1 . For heifers in experiment 2, daily methane production was similar $(P=0.35)$ for MS and GS diets $(194 \mathrm{~g} / \mathrm{d}, 27 \mathrm{~g} /$ $\mathrm{kg}$ of DMI, $27 \mathrm{~g} / \mathrm{kg}$ of OMI, $36 \mathrm{~g} / \mathrm{kg}$ of OMD intake, and $2.3 \mathrm{~g} / \mathrm{kg}$ of $\mathrm{BW}^{0.75}$; Table 5), with ELS having no effect $(P>0.24)$.

\section{Energy and Nitrogen Utilization}

Heifers fed MS in experiment 1 had greater $(P<$ $0.05) \mathrm{GE}$ and $\mathrm{ME}$ intakes, greater fecal energy excretion $(P<0.01)$ and heat production $(P<0.02)$, and less $(P<0.05)$ urinary energy excretion compared with GS (Table 6). Methane energy output differed ( $P$ $<0.05$ ) between diets when expressed as a percentage of intake energy (IE) and digestible energy (DE). An interaction $(P<0.05)$ between forage type and ELS was also noted when methane was expressed as a percent of DE, with a decrease with ELS for MS but not for GS. Energy losses of heat $(P<0.05)$, DE $(P<$ $0.08)$, and urine $(P<0.01)$ as a percentage of IE were lower for heifers fed MS compared with GS. Heifers fed MS retained more tissue energy $(P<0.01)$ than those fed GS. No effect of ELS on energy balance of heifers in experiment 1 was seen, except for decreased methane emission and increased $\mathrm{ME}$ as a percentage of IE $(P<0.10)$. For experiment 2 (Table 7$)$, both diet and ELS had no effect on energy utilization in heifers.

For $\mathrm{N}$ utilization, fecal $\mathrm{N}$ output was greater $(P<$ 0.01) for MS compared with GS diets in experiment 1. In contrast, heifers of experiment 2 fed MS had a lower $(P<0.08) \mathrm{N}$ intake and fecal $\mathrm{N}$ loss $(P<0.01)$ than those fed GS. No overall effect of diet on tissue N retention was observed in either experiment. Extruded linseed supplementation had no effect on $\mathrm{N}$ utilization in either experiment except for a decreased $(P<0.08)$ fecal $\mathrm{N}$ output and increased $\mathrm{N}$ digestion as a percentage of $\mathrm{N}$ intake $(P<0.08)$ for heifers of experiment 2 (Table 8).

\section{Comparison of Heifer BW}

Data sets of experiments 1 and 2 were combined to examine the effect of BW class (i.e., heavier heifers of experiment 1 vs. lighter heifers of experiment 2) and associated differences in forage sources on diet composition, feed intake, whole-tract apparent digestibility, and methane emissions (Table 9). No difference was noted between heavy and light heifers when DMI was expressed relative to $\mathrm{BW}\left(\mathrm{kg}\right.$ or $\left.\mathrm{kg}^{0.75}\right)$. With regards to diet composition, DM content was greater $(P<0.02)$ for experiment 1 , but OM content was lower $(P<0.01)$, compared with experiment 2. No difference in NDF or starch content of the diets offered in the 2 experiments was observed. Heavier heifers in experiment 1 consumed more $(P<0.01)$ DM, OM, and starch than lighter heifers in experiment 2, but NDF intakes were not affected. The starch-to-NDF intake ratio was greater $(P<0.03)$ for experiment 1 compared with experiment 2 . Heavier heifers in experiment 1 had greater $(P<0.07)$ DMD than lighter heifers in experiment 2 , which was also the 
Table 6. Energy utilization in growing dairy heifers fed high-maize (MS) or high-grass silage (GS) diets supplemented without or with extruded linseed [ELS; MS with ELS (ML) and GS with ELS (GL)] in experiment 1

\begin{tabular}{|c|c|c|c|c|c|c|c|c|}
\hline \multirow[b]{2}{*}{ Item } & \multicolumn{4}{|c|}{ Diet } & \multirow[b]{2}{*}{ SEM } & \multicolumn{3}{|c|}{$P$-value } \\
\hline & MS & ML & GS & GL & & Diet (D) & ELS & $\mathrm{D} \times \mathrm{ELS}$ \\
\hline Intake & 167 & 176 & 139 & 142 & 6.95 & 0.012 & 0.131 & 0.290 \\
\hline Fecal & 49.5 & 50.7 & 33.8 & 32.1 & 3.57 & 0.002 & 0.829 & 0.289 \\
\hline Digested & 126 & 128 & 99.4 & 105 & 4.73 & 0.001 & 0.420 & 0.674 \\
\hline Urine & 3.17 & 3.52 & 5.00 & 4.78 & 0.58 & 0.050 & 0.918 & 0.665 \\
\hline Heat & 85.6 & 83.7 & 74.0 & 78.4 & 3.64 & 0.018 & 0.643 & 0.273 \\
\hline Tissue & 25.2 & 29.6 & 9.26 & 10.2 & 3.26 & 0.001 & 0.383 & 0.562 \\
\hline \multicolumn{9}{|c|}{ Percentage of intake energy, $\%$} \\
\hline Digested & 72.0 & 72.5 & 75.1 & 75.4 & 1.67 & 0.078 & 0.806 & 0.963 \\
\hline Urine & 1.83 & 2.01 & 3.78 & 3.48 & 0.41 & 0.009 & 0.897 & 0.624 \\
\hline Methane & 6.86 & 6.13 & 8.47 & 8.01 & 0.38 & 0.001 & 0.064 & 0.624 \\
\hline $\mathrm{ME}$ & 63.4 & 64.3 & 62.8 & 63.9 & 1.39 & 0.682 & 0.421 & 0.981 \\
\hline $\mathrm{ME}$ & 88.0 & 88.5 & 83.8 & 85.0 & 0.43 & 0.021 & 0.093 & 0.222 \\
\hline Heat & 68.0 & 65.7 & 74.7 & 75.1 & 2.25 & 0.005 & 0.630 & 0.496 \\
\hline Tissue & 20.0 & 23.1 & 9.01 & 9.67 & 2.47 & 0.001 & 0.386 & 0.569 \\
\hline
\end{tabular}

case for $\operatorname{OMD}(P<0.03)$ and NDF $(P<0.01)$. Heifer BW (experiment) had no effect $(P=0.12)$ on methane production $(\mathrm{g} / \mathrm{d})$ or yield $(\mathrm{g} / \mathrm{kg}$ of $\mathrm{DMI}$ and $\mathrm{g} / \mathrm{kg}$ of OMI), but methane emission was lower $(P<0.05)$ for heavy heifers of experiment 1 when expressed as grams per kilogram of OMD intake.

\section{DISCUSSION}

Differences in heifer BW appeared to be of little consequence for methane emissions. Our hypotheses were only partly accepted in that heifers fed MS at a heavier BW in experiment 1 emitted $20 \%$ less methane per unit

Table 7. Energy utilization in growing dairy heifers fed high-maize (MS) or high-grass silage (GS) diets supplemented without or with extruded linseed [ELS; MS with ELS (ML) and GS with ELS (GL)] in experiment 2

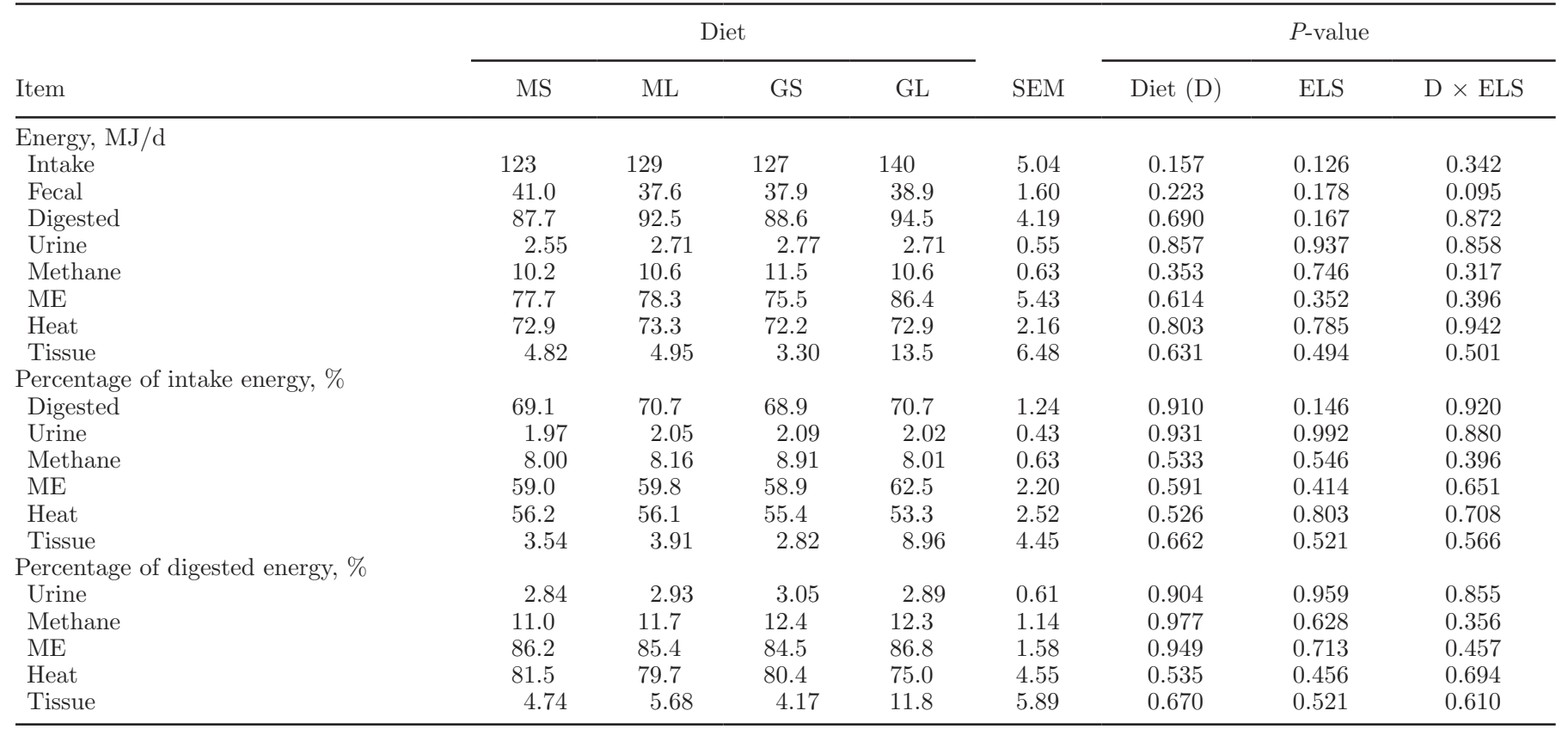


Table 8. Nitrogen utilization (g/d) in growing dairy heifers fed high-maize (MS) or high-grass silage (GS) diets, supplemented without or with extruded linseed [ELS; MS with ELS (ML) and GS with ELS (GL)] for experiments 1 and 2

\begin{tabular}{|c|c|c|c|c|c|c|c|c|}
\hline \multirow[b]{2}{*}{ Item } & \multicolumn{4}{|c|}{ Diet } & \multirow[b]{2}{*}{ SEM } & \multicolumn{3}{|c|}{$P$-value } \\
\hline & MS & ML & GS & GL & & Diet (D) & ELS & $\mathrm{D} \times \mathrm{ELS}$ \\
\hline \multicolumn{9}{|c|}{ Experiment 1} \\
\hline \multicolumn{9}{|l|}{$\mathrm{N}, \mathrm{g} / \mathrm{d}$} \\
\hline Intake & 228 & 224 & 223 & 218 & 12.4 & 0.479 & 0.494 & 0.974 \\
\hline Fecal & 77.7 & 78.5 & 70.9 & 62.1 & 4.40 & 0.007 & 0.105 & 0.085 \\
\hline Digested & 148 & 144 & 161 & 151 & 10.7 & 0.340 & 0.444 & 0.667 \\
\hline Urine & 75.5 & 71.4 & 80.4 & 95.4 & 14.6 & 0.386 & 0.736 & 0.561 \\
\hline Tissue & 74.5 & 84.9 & 64.9 & 54.7 & 14.7 & 0.271 & 0.994 & 0.551 \\
\hline \multicolumn{9}{|c|}{ Percentage of $\mathrm{N}$ intake, $\%$} \\
\hline Fecal & 33.9 & 34.9 & 32.6 & 28.8 & 2.01 & 0.087 & 0.462 & 0.231 \\
\hline Digested & 66.1 & 65.1 & 67.4 & 71.2 & 2.01 & 0.087 & 0.462 & 0.231 \\
\hline Urine & 32.9 & 32.0 & 35.5 & 44.4 & 6.23 & 0.325 & 0.594 & 0.514 \\
\hline Tissue & 32.0 & 35.2 & 30.5 & 24.8 & 6.55 & 0.458 & 0.870 & 0.569 \\
\hline \multicolumn{9}{|c|}{ Experiment 2} \\
\hline \multicolumn{9}{|c|}{$\mathrm{N}, \mathrm{g} / \mathrm{d}$} \\
\hline Intake & 161 & 166 & 171 & 181 & 4.77 & 0.081 & 0.139 & 0.346 \\
\hline Fecal & 53.3 & 53.6 & 65.8 & 64.2 & 2.27 & 0.001 & 0.428 & 0.231 \\
\hline Digested & 111 & 111 & 105 & 116 & 4.92 & 0.912 & 0.241 & 0.230 \\
\hline Urine & 62.8 & 54.1 & 50.4 & 50.6 & 3.12 & 0.110 & 0.312 & 0.295 \\
\hline Tissue & 38.6 & 48.0 & 52.7 & 58.3 & 12.7 & 0.319 & 0.588 & 0.910 \\
\hline \multicolumn{9}{|c|}{ Percentage of $\mathrm{N}$ intake, $\%$} \\
\hline Fecal & 33.4 & 31.8 & 39.1 & 35.9 & 1.42 & 0.013 & 0.075 & 0.419 \\
\hline Digested & 66.6 & 68.2 & 60.9 & 64.1 & 1.42 & 0.013 & 0.075 & 0.419 \\
\hline Urine & 37.7 & 34.0 & 29.6 & 27.9 & 2.78 & 0.115 & 0.403 & 0.776 \\
\hline Tissue & 23.0 & 26.6 & 30.6 & 33.2 & 5.13 & 0.126 & 0.151 & 0.470 \\
\hline
\end{tabular}

Table 9. The effect of heifers with 2 differing BW [i.e., heavy (experiment 1) vs. light (experiment 2)], fed high-maize or high-grass silage diets supplemented without or with extruded linseed

\begin{tabular}{|c|c|c|c|c|}
\hline \multirow[b]{2}{*}{ Item $^{1}$} & \multicolumn{2}{|c|}{ BW class } & \multirow[b]{2}{*}{ SEM } & \multirow{2}{*}{$\frac{P \text {-value }}{\text { BW class }}$} \\
\hline & Heavy & Light & & \\
\hline \multicolumn{5}{|l|}{ BW } \\
\hline $\mathrm{kg}$ & 451 & 362 & 10.7 & 0.001 \\
\hline $\mathrm{DMI} / \mathrm{kg}$ of BW & 0.02 & 0.02 & 0.01 & 0.186 \\
\hline $\mathrm{DMI} / \mathrm{kg}$ of $\mathrm{BW}^{0.75}$ & 0.09 & 0.09 & 0.01 & 0.634 \\
\hline \multicolumn{5}{|l|}{ Diet composition, $\mathrm{g} / \mathrm{kg}$} \\
\hline DM & 453 & 500 & 2.64 & 0.001 \\
\hline $\mathrm{OM}$ & 949 & 962 & 0.64 & 0.001 \\
\hline NDF & 329 & 332 & 3.16 & 0.650 \\
\hline $\mathrm{CP}$ & 162 & 147 & 2.22 & 0.003 \\
\hline Starch & 212 & 212 & 2.18 & 0.830 \\
\hline \multicolumn{5}{|l|}{ Component intake, $\mathrm{kg} / \mathrm{d}$} \\
\hline $\mathrm{DM}$ & 8.89 & 6.98 & 0.23 & 0.004 \\
\hline $\mathrm{OM}$ & 8.46 & 6.73 & 0.21 & 0.008 \\
\hline $\mathrm{NDF}$ & 2.73 & 2.40 & 0.13 & 0.113 \\
\hline Starch & 1.96 & 1.52 & 0.07 & 0.004 \\
\hline Starch:NDF intake ratio & 0.72 & 0.65 & 0.03 & 0.028 \\
\hline \multicolumn{5}{|l|}{ Apparent digestibility, $\mathrm{g} / \mathrm{kg}$} \\
\hline DM & 746 & 728 & 5.80 & 0.069 \\
\hline $\mathrm{OM}$ & 777 & 753 & 6.29 & 0.029 \\
\hline NDF & 658 & 508 & 7.00 & 0.001 \\
\hline Starch & 985 & 983 & 1.39 & 0.514 \\
\hline \multicolumn{5}{|l|}{ Methane emissions } \\
\hline $\mathrm{g} / \mathrm{d}$ & 205 & 194 & 8.64 & 0.398 \\
\hline $\mathrm{g} / \mathrm{kg}$ of $\mathrm{DMI}$ & 24.0 & 26.9 & 1.10 & 0.113 \\
\hline $\mathrm{g} / \mathrm{kg}$ of $\mathrm{OMI}$ & 25.2 & 27.6 & 2.02 & 0.160 \\
\hline $\mathrm{g} / \mathrm{kg}$ of OMD intake & 32.4 & 36.6 & 1.19 & 0.052 \\
\hline $\mathrm{g} / \mathrm{kg}$ of $\mathrm{BW}^{0.75}$ & 2.10 & 2.34 & 0.10 & 0.132 \\
\hline
\end{tabular}

${ }^{1} \mathrm{OMI}=\mathrm{OM}$ intake; $\mathrm{OMD}=\mathrm{OM}$ digestibility. 
of feed intake compared with GS diets; however, when repeated with heifers of a lower BW and using different sources of silage in experiment 2, methane emissions did not differ between the 2 diets. Contrary to expectations and irrespective of heifer BW groups, no effect of ELS on methane emissions was observed.

\section{MS Versus GS}

With increasing maize crop maturity, starch content increases and fiber content decreases as a result of the ear making up a greater proportion of the total crop DM (Bal et al., 1997; Cammell et al., 2000; McGeough et al., 2010). For both experiments, MS diets had greater starch and lower fiber contents than GS diets, in spite of greater wheat inclusion for GS diets; but the MS diets fed in experiment 1 had greater starch and lower fiber content than in experiment 2. Heifers fed MS consumed more DM compared with GS in experiment 1, but this was not the case for experiment 2 . This may have been partially attributed to differences in starch and fiber concentrations and degradation rates for the diets fed and their effects on rumen fill. The greater starch and WSCHO concentrations in GS diets fed to heifers of experiment 2, compared with GS diets fed in experiment 1 , were partly due to the addition of calf pellets and wheat to the TMR, in addition to the composition of the forages. Further, heifers in experiment 2 were fed for a lower LWG; however, heifers in both experiments were at near ad libitum intake and had feed refusals.

Replacing GS with MS in the diet decreases methane emissions to varying extents from ruminants. In the present study, however, heifers fed MS in experiment 1 emitted $20 \%$ less methane ( $\mathrm{g} / \mathrm{kg}$ of DMI) compared with those fed GS; when repeated with different heifers and different silages in experiment 2, though, no difference was observed. McCourt et al. (2007) found methane yields $(\mathrm{g} / \mathrm{kg}$ of DMI) were greater for lactating cows offered GS (27.4) than those given MS (24.8). Reynolds et al. (2010) reported a $13 \%$ decrease in methane yield (g/ $\mathrm{kg}$ of DMI) from lactating cows when replacing GS (23.4) with MS (20.3) in a TMR. Similarly, Brask et al. (2013), found lactating dairy cows fed early- and latematuring GS produced more methane than when fed MS (21.3 vs. 22.8 vs. $19.0 \mathrm{~g} / \mathrm{kg}$ of DMI, respectively); more recently, van Gastelen et al. (2015) found that methane yield was reduced by $11 \%$ for a MS diet in comparison with GS fed to lactating cows. On the other hand, Staerfl et al. (2012) found no difference in methane yields ( $\mathrm{g} / \mathrm{kg}$ of DMI) from fattening bulls fed MS or GS at 5 mo of age (15.2 vs. 14.6, respectively); however, at 9 mo of age, bulls fed MS compared with GS emitted less (15.1 vs. 16.7 , respectively), but then emitted more at $11 \mathrm{mo}$ (19.0 vs. 16.6, respectively). More recently, Livingstone et al. (2015) also reported no effect on methane yield ( $\mathrm{g} / \mathrm{kg}$ of DMI) when replacing GS with MS (21.0 vs. 20.4, respectively) in a TMR for lactating dairy cows. It has been suggested that inconsistent effects of MS versus GS on ruminant methane emissions are related to the source of starch and NDF affecting rates of fermentation in the rumen. Livingstone et al. (2015) concluded that a greater concentration of NDF in their higher-MS diets may have counteracted negative effects of a greater starch concentration and MS composition per se on methane yield compared with higher-GS diets. Starch composition was not given in the study by Staerfl et al. (2012), and therefore the mixed response in methane emissions from bulls fed MS or GS cannot be assumed to be accounted for by differences in dietary starch content and intake. The 3 -fold greater starch concentration and intake, lower NDF concentration and intake, as well as greater DMI for heifers fed MS compared with GS in experiment 1 may explain the lower methane yields for these heifers. Additionally, this explanation could extend to experiment 2, where similar methane yields from heifers fed MS and GS may have been attributed to less of a difference in both starch and NDF concentrations and intakes between forage sources, as well as similar DMI.

Increased feed intakes, as observed for heifers fed MS compared with GS in experiment 1, would be predicted to increase the flow of digesta from the rumen, leaving less time for microbial fermentation of the feed, and a reduction of feed component fermentation in the rumen and, thus, methane production (Yan et al., 2010). In addition to increasing feed intake, high-starch diets are known to be an efficient method for lowering enteric methane emissions (Benchaar et al., 2001; Beauchemin et al., 2008; Martin et al., 2010), although reports are conflicting (Hatew et al., 2013). It is probable that extra starch in MS compared with GS diets, particularly as observed for experiment 1, alters fermentation in ways that decrease methane production (Brask et al., 2013). With increasing starch concentrations, an associated decrease in rumen $\mathrm{pH}$ occurs that can decrease fiber digestion (by inhibition of fibrolytic microbes) and may cause an inhibition of methanogen activity, and therefore methane production (Van Kessel and Russell, 1996; Moss et al., 2000; Janssen, 2010). McGeough et al. (2010) fed steers MS at 4 increasing levels of maturity whereby starch content increased (from 313 to 350 to 364 to $368 \mathrm{~g} / \mathrm{kg}$ of DM), and respective NDF content decreased (from 408 to 385 to 373 to $370 \mathrm{~g} / \mathrm{kg}$ of DM). Methane yield was found to decline with increasing MS maturity (29.4 to 25.8 to 27.7 to $26.2 \mathrm{~g} / \mathrm{kg}$ of DMI). 
For both experiments, heifers fed MS had a lower OMD and fiber digestibility compared with GS diets, suggesting that the starch content of MS diets may have affected fibrolytic bacteria and, therefore, digestibility to some extent. In contrast to the present study, Browne et al. (2005) found the inclusion of MS in the diet had a positive effect on DMD, OMD, and energy digestibility. Phipps et al. (1995), however, found that feeding MS and GS of a similar OMD to lactating dairy cows resulted in MS fed cows having a greater DMI than cows fed GS.

Heifers fed MS in experiment 1 had greater energy intakes, and energy losses in methane, urine, and heat as a percentage of energy intake were less than heifers fed GS. Energy used for tissue retention was also greater for heifers fed MS compared with GS in experiment 1. In contrast, when van Gastelen et al. (2015) increased the proportion of MS versus GS in diets fed to lactating dairy cows all parameters related to energy balance were unaffected by diet, although methane yield decreased. In the present study, greater urine energy excretion for heifers fed GS accompanied greater urine $\mathrm{N}$ excretion, which likely reflects greater urea excretion. For heifers of experiment 2, where no differences in methane emission were measured, energy metabolism did not differ between diets.

Previous comparisons between MS- and GS-based diets have reported inconsistent effects on $\mathrm{N}$ utilization. Often this has been attributed to relative $\mathrm{CP}$ concentration, source or amount of supplementary CP offered, and rumen fermentable carbohydrate supply. Browne et al. (2005) found $\mathrm{N}$ excreted in feces and urine increased as MS replaced GS, but relative to $\mathrm{N}$ intake it was greater for GS, which is similar to results of experiment 2. A linear increase in efficiency of intake $\mathrm{N}$ use for milk $\mathrm{N}$ excretion was observed when MS was increased as a proportion of a GS diet fed to lactating cows (van Gastelen et al., 2015), and Moss et al. (1992) found an improvement in $\mathrm{N}$ balance for sheep fed GS with the addition of MS, postulating this was due to more readily fermentable carbohydrate which improved microbial $\mathrm{N}$ capture. Lack of differences in $\mathrm{N}$ balance for heifers fed MS or GS diets in either of our experiments may have been due to the relatively small differences in $\mathrm{N}$ intake across diets.

\section{Oil Supplementation}

No effect of ELS on methane emission was noted in the present study, which was likely due to the relatively low amount of supplemental oil fed. With the addition of the ELS, diet oil concentration increased by 1.32 and 1.31 percentage units for MS and GS diets, respectively, for experiment 1 , and 0.85 and 1.87 percentage units for MS and GS diets, respectively, for experiment 2 . A similar conclusion was given by Livingstone et al. (2015) when ELS was added at 5\% of ration DM. However, as noted by Livingstone et al. (2015), the amount of ELS included in diets used for the present study was more than double the recommended inclusion rate for dairy cows fed commercial diets. Patra (2013) recently performed a meta-analysis of 29 experiments and concluded that oils with a high concentration of C12:0, C18:0, and PUFA, included at $6 \%$ of dietary DM, in general, should be an effective feeding strategy for mitigating methane emissions without detrimental effects in dairy cattle productivity. Although not measured in the present study, the concentrations of PUFA in linseed oil are typically high (greater than $70 \%$ of total FA). Despite this, it is recognized that the addition of oil to the diets of ruminants to mitigate methane emissions is not consistently effective (McAllister et al., 1996; Beauchemin et al., 2008) and is dependent upon concentration, type, FA composition, and composition of the basal diet (Beauchemin et al., 2008). The dietary forage-to-concentrate ratio has been reported to be important for modulating the response of oil supplementation on ruminal digestibility (Ben Salem et al., 1993; Ueda et al., 2003). Linseed oil supplementation may inhibit fiber digestion when diets contain a high proportion of concentrate or starch (Ueda et al., 2003); however, this was not the case in the present study. Ben Salem et al. (1993) concluded that on a fiber-rich diet, FA would be absorbed on particles and be more diluted in the rumen content, and therefore less interactive with bacteria. The fiber content in both the MS and GS diets offered in both experiments in our study may have influenced effects of ELS on methane emission; however, no significant interactions were noted between forage type and ELS.

\section{Heifer BW}

There was no effect of heifer BW on methane emissions; however, in our study, BW was confounded with experiment and associated differences in forage source and measurement periods. Staerfl et al. (2012) reported differences in methane yields from fattening bulls fed MS and GS diets at 9 and 11 mo of age, but no difference at 5 mo of age. This age-dependent effect was put down to development of the rumen, changing digesta kinetics, and a more efficient archaeal population, although those authors concluded that the data set was too small to claim an effect of animal age on methane yield. In the present study, differences in BW were associated with a relatively minor difference in chronological age. 


\section{CONCLUSIONS}

Although dietary manipulation is an obvious strategy for reducing methane emissions from ruminants, effects of forage source on methane were not consistent in the present study. Heifers at a heavier BW fed MS emitted less methane per unit of feed intake than when fed GS diets; however, when repeated with heifers of a lower BW and a different source of forage, methane emissions did not differ between the 2 diets. No effect of ELS was observed on any of the variables measured and we concluded that this was due to the relatively low level included in the diet. Consequently, considering that MS and GS are applicable to rations fed in the United Kingdom, further work is needed to determine the specific forage composition and characteristics of these forages that determine methane emissions from ruminant livestock.

\section{ACKNOWLEDGMENTS}

This study was funded by the Department for Environment Food \& Rural Affairs (Defra, London, UK), the Scottish Government (Edinburgh, UK), the Department of Agriculture and Rural Development (Belfast, UK), and the Welsh Government (Cardiff, UK) as part of the United Kingdom's Agricultural greenhouse gas Research Platform project (www.ghgplatform.org.uk). Contributions from the technical staff of the University of Reading's Centre for Dairy Research Metabolism Unit in the daily routine of experiments and care of cows, as well as analysis of samples by staff of the University of Reading Metabolism Laboratory is gratefully acknowledged.

\section{REFERENCES}

Alderman, G., and B. R. Cottrill. 1993. Energy and Protein Requirements of Ruminants: An Advisory Manual Prepared by the AFRC Technical Committee on Responses to Nutrients. CAB International, Wallingford, UK.

Bal, M. A., J. G. Coors, and R. D. Shaver. 1997. Impact of the maturity of corn for use as silage in the diets of dairy cows on intake, digestion, and milk production. J. Dairy Sci. 80:2497-2503.

Beauchemin, K. A., M. Kreuzer, F. P. O'Mara, and T. A. McAllister 2008. Nutritional management for enteric methane abatement: A review. Aust. J. Exp. Agric. 48:21-27.

Ben Salem, H., R. Krzeminski, A. Ferlay, and M. Doreau. 1993. Effect of lipid supply on in vivo digestion in cows: Comparison of hay and corn silage diets. Can. J. Anim. Sci. 73:547-557.

Benchaar, C., C. Pomar, and J. Chiquette. 2001. Evaluation of dietary strategies to reduce methane production in ruminants: A modelling approach. Can. J. Anim. Sci. 81:563-574.

Brask, M., P. Lund, A. L. F. Hellwing, M. Poulsen, and M. R. Weisbjerg. 2013. Enteric methane production, digestibility and rumen fermentation in dairy cows fed different forages with and without rapeseed fat supplementation. Anim. Feed Sci. Technol. 184:67-69.

Brouwer, E. 1965. Report of sub-committee on constants and factors Pages 441-443 in Proc. 3rd Symp. Energy Metabolism. Academic Press, London, UK.
Browne, E. M., D. T. Juniper, M. J. Bryant, and D. E. Beever. 2005. Apparent digestibility and nitrogen utilisation of diets based on maize and grass silage fed to beef steers. Anim. Feed Sci. Technol. 119:55-68.

Cammell, S. B., J. D. Sutton, D. E. Beever, D. J. Humphries, and R. H. Phipps. 2000. The effect of crop maturity on the nutritional value of maize silage for lactating dairy cows 1 . Energy and nitrogen utilization. Anim. Sci. 71:381-390.

Cammell, S. B., D. J. Thomson, D. E. Beever, M. J. Haines, M. S. Dhanoa, and M. C. Spooner. 1986. The efficiency of energy utilization in growing cattle consuming fresh perennial ryegrass (Lolium perenne cv. Melle) or white clover (Trifolium repens cv. Blanca) Br. J. Nutr. 55:669-680

Cottle, D. J., J. V. Nolan, and S. G. Wiedemann. 2011. Ruminant enteric methane mitigation: A review. Anim. Prod. Sci. 51:491-514.

Grainger, C., and K. A. Beauchemin. 2011. Can enteric methane emissions from ruminants be lowered without lowering their production? Anim. Feed Sci. Technol. 166-167:308-320.

Hammond, K. J., D. J. Humphries, L. A. Crompton, C. Green, and C. K. Reynolds. 2015. Methane emissions from cattle: Estimates from short-term measurements using a GreenFeed system compared with measurements obtained using respiration chambers or sulphur hexafluoride tracer. Anim. Feed Sci. Technol. 203:41-52. http://dx.doi.org/10.1016/j.anifeedsci.2015.02.008.

Hammond, K. J., D. J. Humphries, D. B. Westbury, A. Thompson, L. A. Crompton, P. Kirton, C. Green, and C. K. Reynolds. 2014. The inclusion of forage mixtures in the diet of growing dairy heifers: Impacts on digestion, energy utilisation, and methane emissions. Agric. Ecosyst. Environ. 197:88-95.

Hatew, B., S. C. Podesta, H. van Laar, W. F. Pellikaan, J. L. Ellis, J. Dijkstra, and A. Bannink. 2013. Effects of type and level of starch in concentrate on methane emission in lactating dairy cows. Page 499 in Proc. Proc. 5th Ann. Greenhouse Gases and Animal Conference: Advances in Animal Biosciences. Cambridge University Press, Dublin, Ireland.

Janssen, P. H. 2010. Influence of hydrogen on rumen methane formation and fermentation balances through microbial growth kinetics and fermentation thermodynamics. Anim. Feed Sci. Technol. 160:1-22.

Johnson, K. A., and D. E. Johnson. 1995. Methane emissions from cattle. J. Anim. Sci. 73:2483-2492.

Livingstone, K. M., D. J. Humphries, P. Kirton, K. E. Kliem, D. I. Givens, and C. K. Reynolds. 2015. Effects of forage type and extruded linseed supplementation on methane production and milk fatty acid composition of lactating dairy cows. J. Dairy Sci. In press.

Martin, C., D. P. Morgavi, and M. Doreau. 2010. Methane mitigation in ruminants: From microbe to the farm scale. Animal 4:351-365.

Martin, C., J. Rouel, J. P. Jouany, M. Doreau, and Y. Chilliard. 2008 Methane output and diet digestibility in response to feeding dairy cows crude linseed, extruded linseed, or linseed oil. J. Anim. Sci. $86: 2642-2650$

McGeough, E. J., P. O'Kiely, P. A. Foley, K. J. Hart, T. M. Boland, and D. A. Kenny. 2010. Methane emissions, feed intake, and performance of finishing beef cattle offered maize silages harvested at 4 different stages of maturity. J. Anim. Sci. 88:1479-1491.

McAllister, T., E. Okine, G. Mathison, and K.-J. Cheng. 1996. Dietary, environmental and microbiological aspects of methane production in ruminants. Can. J. Anim. Sci. 76:231-243.

McCourt, A. R., T. Yan, and C. S. Mayne. 2007. Effect of forage type on methane production from dairy cows. Page 48 in Proc. Br. Soc. Anim. Sci. BSAS, Southport, UK.

Moate, P. J., S. R. O. Williams, C. Grainger, M. C. Hannah, E. N Ponnampalam, and R. J. Eckard. 2011. Influence of cold-pressed canola, brewers grains and hominy meal as dietary supplements suitable for reducing enteric methane emissions from lactating dairy cows. Anim. Feed Sci. Technol. 166-167:254-264.

Morgavi, D. P., E. Forano, C. Martin, and C. J. Newbold. 2010 Microbial ecosystem and methanogenesis in ruminants. Animal 4:1024-1036. 
Moss, A., J. Jouany, and J. Newbold. 2000. Methane production by ruminants: Its contribution to global warming. Anim. Res. 49:231253.

Moss, A. R., D. I. Givens, and R. H. Phipps. 1992. Digestibility and energy value of combinations of forage mixtures. Anim. Feed Sci. Technol. 39:151-172.

Nagaraja, T. G., C. J. Newbold, and C. J. Van Nevel. 1997. Manipulation of ruminal fermentation. Pages 523-632 in The Rumen Microbial Ecosystem. 2nd ed. P. Hobson and C. Stewart, ed. Blackie Academic \& Professional, London, UK.

O'Mara, F. P., J. J. Fitzgerald, J. J. Murphy, and M. Rath. 1998. The effect on milk production of replacing grass silage with maize silage in the diet of dairy cows. Livest. Prod. Sci. 55:79-87.

Owens, D., M. McGee, T. Boland, and P. O'Kiely. 2009. Rumen fermentation, microbial protein synthesis, and nutrient flow to the omasum in cattle offered corn silage, grass silage, or whole-crop wheat. J. Anim. Sci. 87:658-668.

Patra, A. K. 2013. The effect of dietary fats on methane emissions, and its other effects on digestibility, rumen fermentation and lactation performance in cattle: A meta-analysis. Livest. Sci. 155:244-254.

Phipps, R. H., J. D. Sutton, and B. A. Jones. 1995. Forage mixtures for dairy cows: The effect on dry-matter intake and milk production of incorporating either fermented or urea-treated whole-crop wheat, brewers' grains, fodder beet or maize silage into diets based on grass silage. Anim. Sci. 61:491-496.

Reynolds, C. K., L. A. Crompton, J. A. N. Mills, D. J. Humphries, P. Kirton, A. E. Relling, T. H. Misselbrook, D. R. Chadwick, and D. I. Givens. 2010. Effects of diet protein level and forage source on energy and nitrogen balance in methane and nitrogen excretion in lactating dairy cows. Page 736 in Energy and Protein Metabolism and Nutrition. Vol. 127. G. M. Crovetto, ed. Wageningen Academic Publishers, Wageningen, The Netherlands.

Reynolds, C. K., D. J. Humphries, P. Kirton, M. Kindermann, S. Duval, and W. Steinberg. 2014. Effects of 3-nitrooxypropanol on methane emission, digestion, and energy and nitrogen balance of lactating dairy cows. J. Dairy Sci. 97:3777-3789.

Robertson, J. B., and P. J. Van Soest. 1981. The detergent system of analysis and its application to human foods. Pages 123-158 in The Analysis of Dietary Fiber in Food. Vol. 3. W. James and O. Theander, ed. Marcel Dekker Inc., New York, NY.

Staerfl, S. M., J. O. Zeitz, M. Kreuzer, and C. R. Soliva. 2012. Methane conversion rate of bulls fattened on grass or maize silage as compared with the IPCC default values, and the long-term methane mitigation efficiency of adding acacia tannin, garlic, maca and lupine. Agric. Ecosyst. Environ. 148:111-120.

Ueda, K., A. Ferlay, J. Chabrot, J. J. Loor, Y. Chilliard, and M. Doreau. 2003. Effect of linseed oil supplementation on ruminal digestion in dairy cows fed diets with different forage:concentrate ratios. J. Dairy Sci. 86:3999-4007.

United Nations. 2009. World Population Prospects: The 2008 Revision, Highlights. Vol. Working Paper No. ESA/P/WP.210. Accessed Jan. 20, 2014. http://www.un.org/esa/population/publications/ wpp2008/wpp2008_highlights.pdf.

van Gastelen, S., E. C. Antunes-Fernandes, K. A. Hettinga, G. Klop, S. J. J. Alferink, W. H. Hendriks, and J. Dijkstra. 2015. Enteric methane production, rumen volatile fatty acid concentrations, and milk fatty acid composition in lactating Holstein-Friesian cows fed grass silage- or corn silage-based diets. J. Dairy Sci. 98:1915-1927.

Van Kessel, J. S., and J. B. Russell. 1996. The effect of pH on ruminal methanogenesis. FEMS Microbiol. Ecol. 20:205-210.

Yan, T., C. S. Mayne, F. G. Gordon, M. G. Porter, R. E. Agnew, D. C. Patterson, C. P. Ferris, and D. J. Kilpatrick. 2010. Mitigation of enteric methane emissions through improving efficiency of energy utilization and productivity in lactating dairy cows. J. Dairy Sci. 93:2630-2638 